

\title{
Fast RNA conjugations on solid phase by strain-promoted cycloadditions $\uparrow$
}

\author{
Ishwar Singh, ${ }^{a, d}$ Colin Freeman, ${ }^{a}$ Annemieke Madder, ${ }^{b}$ Joseph S. Vyle ${ }^{c}$ and Frances Heaney*a
}

Received 27th March 2012, Accepted 12th June 2012

DOI: $10.1039 / \mathrm{c} 2 \mathrm{ob} 25628 \mathrm{~b}$

Strain promoted cycloaddition is presented as a tool for RNA conjugation on the solid phase; RNA-cyclooctyne conjugates are prepared by cycloaddition to both azide (strain-promoted azide-alkyne cycloaddition, SPAAC) and nitrile oxide dipoles (strain-promoted nitrile oxide-alkyne cycloaddition, SPNOAC). The conjugation is compatible with 2'-OMe blocks and with 2'-O-TBDMS protection on the ribose moieties of the sugar. Nitrile oxide dipoles are found to be more reactive click partners than azides. The conjugation proceeds within $10 \mathrm{~min}$ in aqueous solvents, at room temperature without any metal catalyst and tolerates dipoles of varying steric bulk and electronic demands, including pyrenyl, coumarin and dabcyl derivatives.

\section{Introduction}

Currently, chemically-modified oligonucleotides are in high demand due to their utility in diagnostic, ${ }^{1,2}$ therapeutic, ${ }^{3}$ nanotechnology ${ }^{4}$ and materials science applications. ${ }^{5}$ The most attractive reactions for the chemical transformation of nucleic acid substrates are those which proceed in aqueous media at ambient temperature and tolerate the presence of oxygen.

Although $\mathrm{Cu}(\mathrm{I})$-catalysed azide-alkyne cycloaddition (CuAAC) reactions are widely employed in synthetic chemistry, ${ }^{6}$ materials science, ${ }^{7}$ and in chemical biology ${ }^{8,9}$ the "click" conditions required are not ideal for nucleic acid modification as copper ions mediate Fenton-type DNA damage, leading to strand breaks. ${ }^{8,10,11}$ Although the addition of stabilising ligands can be effective in minimizing this degradation, the toxicity of $\mathrm{Cu}(\mathrm{I})$ still remains potentially problematic. ${ }^{12}$ To overcome these issues, several metal-free bio-conjugation chemistries have been developed. We and others have reported the application of nitrile oxide derivatives to the modification of nucleosides, oligonucleotides and polymers bearing alkene/alkyne functions. ${ }^{13-19}$ Other metal-free strategies include Diels-Alder cycloadditions, ${ }^{20}$ photoinduceable cycloadditions of tetrazines or nitrile imines to

\footnotetext{
${ }^{a}$ Department of Chemistry, NUI Maynooth, Maynooth, Co. Kildare, Republic of Ireland.E-mail: mary.f.heaney@nuim.ie;

Fax: +353 17083815; Tel: +35317083802

${ }^{b}$ Laboratory for Organic and Biomimetic Chemistry Department of Organic Chemistry Krijgslaan 281, S4 B-9000 Gent, Belgium

${ }^{c}$ School of Chemistry and Chemical Engineering, The Queen's

University of Belfast, David Keir Building, Stranmillis Road, Belfast, Northern Ireland

${ }^{d}$ Department of Pure and Applied Chemistry, University of Strathclyde, 295 Cathedral Street, Glasgow G1 1XL, UK.

E-mail: ishwar.singh@strath.ac.uk; Fax:+44 141 5482019;

Tel: +441415483909

$\dagger$ Electronic supplementary information (ESI) available: HPLC and MALDI data. See DOI: 10.1039/c2ob25628b
}

alkenes $^{21,22}$ and strain-promoted azide-alkyne cycloaddition (SPAAC) reactions.

The potential of SPAAC reactions for bio-conjugation was first described by Bertozzi and co-workers in $2004^{23}$ and exploited the intrinsic ring strain of a cyclooctyne moiety. The reactivity of the first generation of monocyclic octynes have subsequently been ameliorated by incorporating a ring heteroatom, ${ }^{24}$ electron withdrawing substituents, ${ }^{20}$ or introducing further strain by fusing two aromatic rings to the (aza)cyclooctyne core, ${ }^{25,26}$ SPAAC reactions have since found applications in bioimaging, ${ }^{24,27}$ peptide conjugation, ${ }^{28}$ drug delivery ${ }^{29}$ and surface and materials science. ${ }^{30,31}$

We have previously reported post-synthetic modification of DNA by strain-promoted cycloaddition of both azide and nitrile oxide dipoles to solid-supported DNA-cyclooctyne substrates. ${ }^{32,33}$ Filippov et al., ${ }^{34}$ and Manoharan et al., ${ }^{35}$ have demonstrated azide-mediated oligonucleotide-dibenzocyclooctyne conjugation in solution phase, using the same methodology as that described for DNA-templated "click"-ligation demonstrated by Brown and El-Sagheer. ${ }^{36}$

As part of an ongoing programme to prepare siRNA conjugates with improved potential for cellular delivery, we became interested in the possibility of RNA functionalization using strain-promoted cycloaddition chemistry. In particular, we were interested in solid-supported RNA substrates bearing monocyclic octynes as handles for conjugation to a variety of ligands/labels. The attractions of solid phase synthesis (SPS) include ease of purification and the possibility to automate the ligation procedure. The choice of a non-substituted cyclooctyne dipolarophile partner for the SPAAC reaction offers advantages in terms of facile synthetic accessibility ${ }^{33}$ and reduced steric bulk and lipophilicity leading to enhanced aqueous solubility with a reduced tendency to give non-specific interactions with hydrophobic proteins. ${ }^{37}$ We wish to report here solid phase, postsynthetic RNA conjugation by SPAAC and strain-promoted 


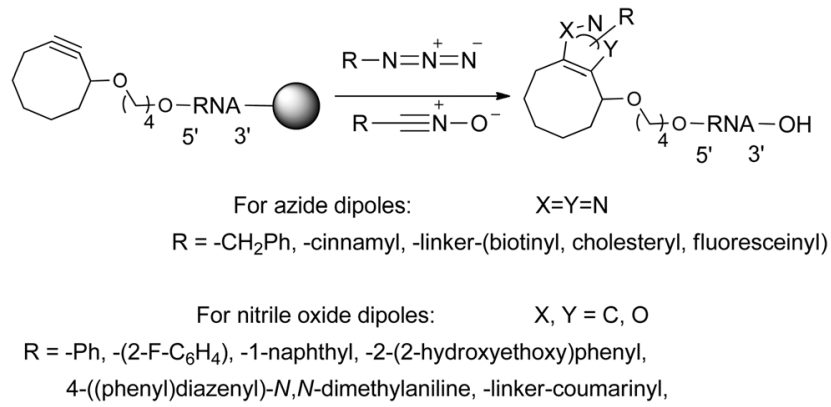

Scheme 1 Solid-supported RNA conjugation by strain-promoted cycloaddition chemistry.

nitrile oxide-alkyne cycloaddition (SPNOAC) reactions as summarised in Scheme 1.

\section{Results and discussion}

RNA substrates 1-5 were prepared using standard solid-phase protocols prior to manual coupling of the cyclooctyne phosphoramidite $\mathbf{6}$ and subsequent oxidation of the terminal phosphite triester (Scheme 2). ${ }^{33}$ Near quantitative conversion of $\mathbf{1 - 5}$ to the putative solid-bound RNA-cyclooctynes (7-11) was indicated by
RP-HPLC and MALDI-TOF-MS analysis of the deprotected oligonucleotide-cyclooctyne conjugates 12-16.

CPG-RNA cyclooctyne 7 and benzyl azide, 17, were selected as model reactants with which to study solid-supported RNA modification by a SPAAC reaction. The reaction was conducted on a $0.1 \mu \mathrm{mol}$ scale (supported oligonucleotide) with 20 equivalents of azide in aqueous DMSO $(50 \% \mathrm{v} / \mathrm{v})$. The reaction was complete within 30 min under ambient conditions (as evidenced by RP-HPLC), and the putative support-bound conjugate 22a was subsequently cleaved from the resin and deprotected to afford the RNA conjugate 23a (Scheme 3, Table 1). HPLC analysis showed formation of putative regioisomeric cycloadducts; MALDI-TOF-MS data was consistent with the structure of 23a. Similarly, 7 was conjugated with cinnamyl azide $18^{38}$ to give regioisomeric products $\mathbf{2 3 b}$ in high yield (by HPLC).

Having established that the solid-supported RNA-cyclooctyne dipolarophile 7 is a suitable substrate for SPAAC with simple azide dipoles, the compatibility of the conditions with labels bearing a range of functionalities was investigated. Thus, 7 was treated with biotinyl-(19), ${ }^{32}$ cholesteryl-(20) ${ }^{32}$ or fluoresceinyl$(\mathbf{2 1})^{32}$ azides in both aqueous and non-aqueous media at room temperature. Conjugation to the biotinyl azide (19), furnished 23c after $4 \mathrm{~h}$ in $90 \%(\mathrm{v} / \mathrm{v})$ aqueous DMSO, whilst DCM was the solvent of choice for cholesteryl conjugation. The success of the SPAAC to furnish lipid conjugates is suggestive of a future in

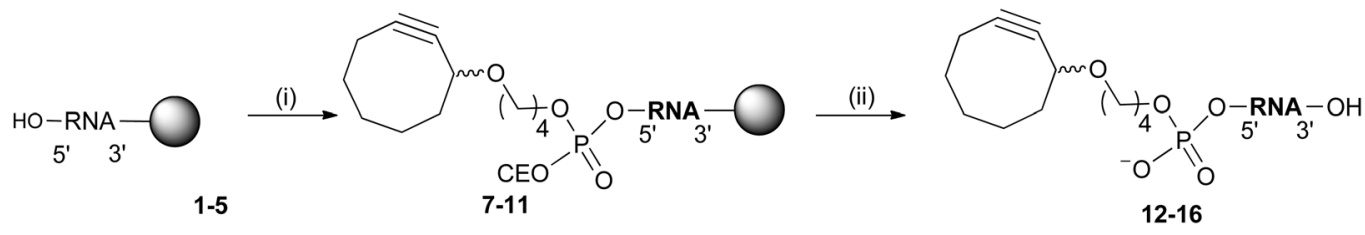

(i) a. 6., BMT, $\mathrm{CH}_{3} \mathrm{CN}$, b. $\mathrm{I}_{2}, \mathrm{RT}$; (ii) Cleavage/deprotection

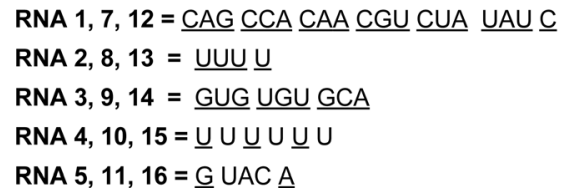

Underlined $=2^{\prime}-$ OMe nucleotides

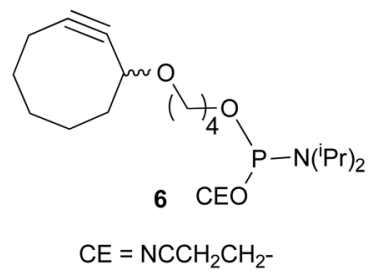

Scheme 2 Solid-supported synthesis of RNAs bearing cyclooctyne "click" partners.

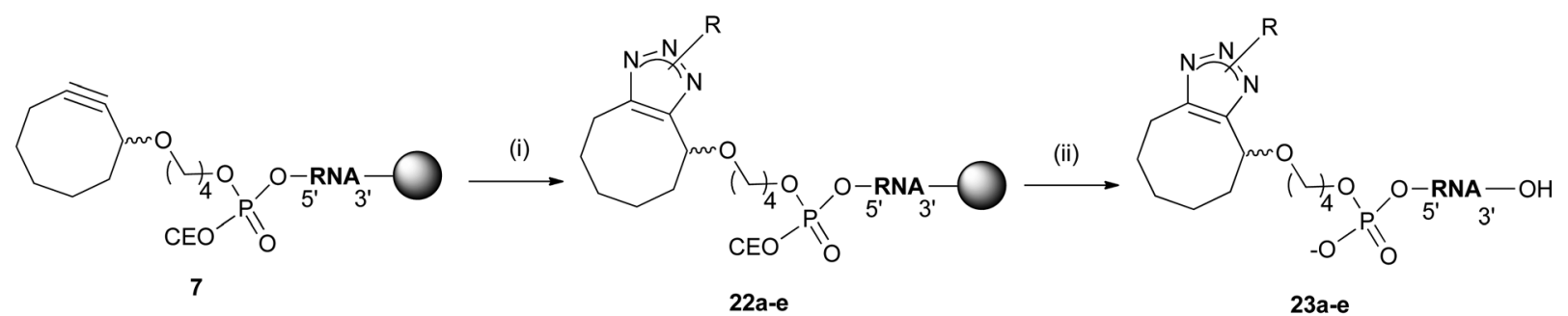

RNA $=\underline{\mathrm{CAG}} \underline{\mathrm{CCA}} \underline{\mathrm{CAA}} \underline{\mathrm{CGU}} \underline{\mathrm{CUA}} \underline{\underline{U A U}} \underline{\mathrm{C}} \quad \mathrm{CE}=\mathrm{NCCH}_{2} \mathrm{CH}_{2}-$

(i) $\mathrm{RN}_{3}, \mathrm{DMSO} / \mathrm{H}_{2} \mathrm{O}$ or DCM, $0.5-20 \mathrm{hr}$.,RT; (ii) Deprotection/cleavage

Scheme 3 SPAAC of RNA-cyclooctyne 7 to form conjugates 23a-e. 
Table 1 Structures of azides 17-21 and triazole conjugates 23a-e

\begin{tabular}{|c|c|c|c|}
\hline Azide, $\mathrm{R}-\mathrm{N}_{3}$ & $\mathrm{R}$ & Resin-supported conjugate & Triazole-conjugate \\
\hline $\begin{array}{l}17 \\
18 \\
19\end{array}$ & $\begin{array}{l}\mathrm{PhCH}_{2} \\
\mathrm{PhCHCHCH}_{2}\end{array}$ & $\begin{array}{l}22 a \\
22 b \\
22 c\end{array}$ & $\begin{array}{l}23 a \\
23 b \\
23 c\end{array}$ \\
\hline 20 & & 22d & 23d \\
\hline 21 & & $22 \mathrm{e}$ & 23e \\
\hline
\end{tabular}

Table 2 Conditions for SPAAC of azides 17-21 with support-bound RNA-cyclooctyne, 7 and MALDI-TOF MS data

\begin{tabular}{lllll}
\hline Azide & Solvent & Reaction time & Product & $\begin{array}{l}\text { MALDI-TOF MS } \\
\text { calculated, found }\end{array}$ \\
\hline $\mathbf{1 7}$ & $50 \%$ aq. DMSO & $30 \mathrm{~min}$ & $\mathbf{2 3 a}$ & 6624,6623 \\
$\mathbf{1 8}$ & $50 \%$ aq. DMSO & $30 \mathrm{~min}$ & $\mathbf{2 3 b}$ & 6650,6650 \\
$\mathbf{1 9}$ & $90 \%$ aq. DMSO & $4 \mathrm{~h}$ & $\mathbf{2 3 c}$ & 6831,6833 \\
$\mathbf{2 0}$ & DCM & $24 \mathrm{~h}$ & $\mathbf{2 3 d}$ & 7018,7020 \\
$\mathbf{2 1}^{a}$ & $90 \%$ aq. DMF & $24 \mathrm{~h}$ & $\mathbf{2 3 e}$ & 6931,6934 \\
${ }^{a}$ Reaction with fluoresceinyl azide & \multicolumn{3}{l}{ was conducted in solution. } \\
\hline
\end{tabular}

drug formulation free from the inherent toxicity which plagues cationic delivery vehicles. $^{39,40}$ The fluorescein azide $\mathbf{2 1}$ was selected to demonstrate the potential of SPAAC for introduction of fluorescent tags. Having previously demonstrated that 21 required post-synthetic conjugation to DNA, ${ }^{32}$ the same strategy was adopted for RNA-cyclooctyne 12. Thus, $12(0.025 \mu \mathrm{mol}$, 1 eq., $200 \mu \mathrm{M})$, obtained from 7 following cleavage from the resin and deprotection, was exposed to a solution of 21 (40 eq.) in aqueous DMF. The reaction, as judged by HPLC, progressed cleanly and was complete in $24 \mathrm{~h}$ at room temperature. The identity and integrity of the conjugate, which retained the yellow colour characteristic of molecules incorporating a tetracyclic fluorescein skeleton, as 23e was supported by MALDI-TOF mass analysis (Table 2).

In formation of the conjugates 23a through d, it was observed that as the steric bulk of the azide partner increased, from benzyl through to cholesterol, the rate of conjugation decreased. Commonly reported strategies which enhance the rate of strainpromoted cycloaddition reactions include the use of activated

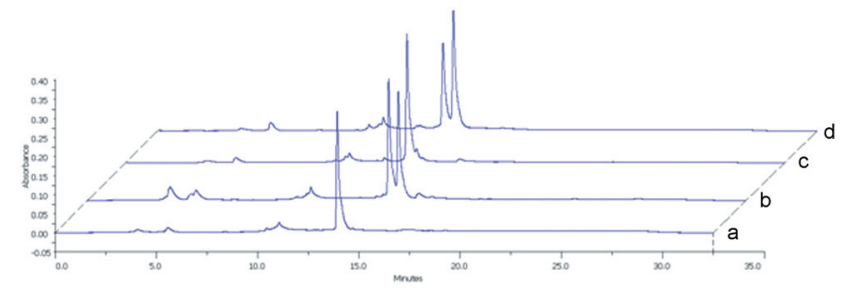

Fig. 1 HPLC traces (recorded at $260 \mathrm{~nm}$ ) of: (a) crude RNA-cyclooctyne 13, resulting from deprotection and cleavage from the support $\mathbf{8}$; and $\mathrm{b}-\mathrm{d}$ ) the crude reaction products resulting from reaction of the RNA-cyclooctyne 8; (b) with phenyl nitrile oxide after 10 min showing regioisomeric cycloadducts; (c) with phenyl azide after 10 min showing no reaction; (d) phenyl azide for $18 \mathrm{~h}$ showing incomplete consumption of starting RNA-cyclooctyne. HPLC analysis conditions A (for a and b) or $\mathrm{C}$ ( for $\mathrm{c}$ and $\mathrm{d}$ ).

cyclooctynes, e.g. dibenzocyclooctynes, ${ }^{25}$ and/or dipoles which are more reactive than the azide, e.g. nitrile oxides. A flip side of the enhanced reactivity of nitrile oxide dipoles is their potential to partake in side reactions, e.g. dimerization, for this reason in exploring the utility of SPNOAC reactions for conjugation to support-bound oligonucleotides the dipoles were generated in situ from stable precursor aryl aldoximes. Thus, a suspension of 8 in $50 \%(\mathrm{v} / \mathrm{v})$ aqueous ethanol was exposed to benzonitrile oxide and reaction progress was followed by RP-HPLC. Conjugation was completed within $10 \mathrm{~min}$ at room temperature (Fig. 1b) and the regioisomeric isoxazole-RNA conjugates 33a were obtained in near quantitative yield following work-up, deprotection and cleavage from the support, (Scheme 4).

The relative rates of the SPAAC and SPNOAC reactions using cycloalkyne $\mathbf{8}$ were compared using phenyl azide and 


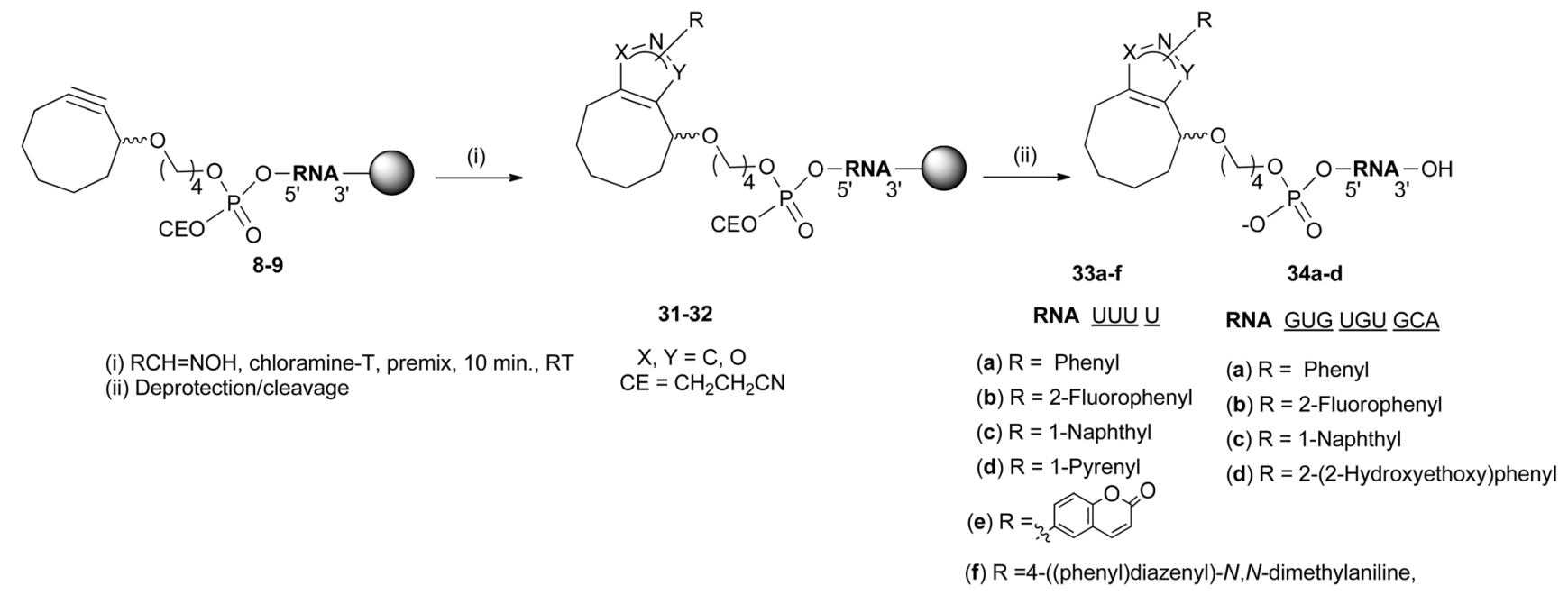

Scheme 4 SPNOAC of RNA-cyclooctynes 8 and $\mathbf{9}$ with a range of nitrile oxides.

benzonitrile oxide, and the success of each reaction judged by HPLC analysis of the crude reaction products (Fig. 1). Whilst reaction with the nitrile oxide was complete in just $10 \mathrm{~min}$ at room temperature, under the same conditions no conjugation was observed with phenyl azide. In fact, even after $18 \mathrm{~h}$ reaction time with the azide dipole, conjugation was still not complete (Fig. 1d). The failure of HPLC to resolve the expected regioisomeric triazoles $23 f(R=P h)$ is not unprecedented. ${ }^{41}$

To demonstrate the scope of SPNOAC reactions, the oximes, 25-30, ${ }^{16,33,42,43}$ (Fig. 2), were selected as nitrile oxide precursors. The analogous dipoles were generated immediately prior to use following $10 \mathrm{~min}$ exposure of the parent oxime to a solution of chloramine-T at room temperature. The choice of solvent was dictated by the solubility of the oxime and product nitrile oxide (Table 3). Thus, as with benzaldoxime, $\mathbf{2 5} \mathbf{2 6}$ and $\mathbf{2 7}$ were dissolved in aqueous EtOH and oxidised to the corresponding nitrile oxides. Addition of the nitrile oxide solutions derived from $\mathbf{2 5}$ and $\mathbf{2 6}$ to the solid-supported oligonucleotide-alkyne $\mathbf{8}$ and of the solutions derived from 25-27 to the solid-supported cyclic alkyne 9, followed by agitation of the mixtures at room temperature for $10 \mathrm{~min}$ gave near quantitative conversion to the regioisomeric isoxazole-conjugates $\mathbf{3 3 b}-\mathbf{c}$ and $\mathbf{3 4 b}-\mathbf{d}$, following deprotection. The identity of these compounds was evidenced by MALDI-TOF-MS analysis.

Pyrene-1-nitrile oxide, coumarin-6-nitrile oxide, and 4-( $N, N$ dimethylamino)phenylazo-benzonitrile oxide, generated in situ,

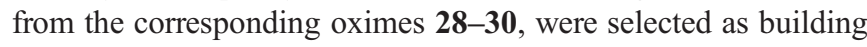
blocks with potential to rapidly introduce reporter groups to RNA substrates. DMF/ethanol was selected as the solvent for dipole generation and cycloaddition, and RNA-8 as the model substrate. In each case, HPLC analysis of the cleaved, deprotected, but unpurified reaction products indicated complete consumption of 8 within $10 \mathrm{~min}$, and formation of regioisomeric mixtures of RNA-conjugates 33d-f (Scheme 4). MALDI-TOF MS data supported the structural integrity of the conjugates 33d-f.

No modification to the reaction conditions was required for conjugation to longer oligonucleotides, and the support-bound 19-mer cyclooctyne 7 was converted, almost quantitatively, to<smiles>O/N=C/c1ccccc1/C=N/O</smiles>

24<smiles>C/C=N/c1cccc2ccccc12</smiles>

26<smiles>OCCOc1ccccc1/C=N/O</smiles>

27<smiles>O=N/C=C/c1ccc2oc(=O)ccc2c1</smiles>

29<smiles>CN(C)c1ccc(N=Nc2ccc(/C=N/O)cc2)cc1</smiles>

30

Fig. 2 Oximes employed as nitrile oxide precursors in synthesis of cycloadducts 33-34, 38-40.

Table 3 Conditions for SPNOAC cycloaddition to support bound RNA-cyclooctynes 7-11 and MALDI-TOF MS data

\begin{tabular}{lllll}
\hline $\begin{array}{l}\text { Dipole } \\
\text { precursor }\end{array}$ & $\begin{array}{l}\text { Reaction } \\
\text { solvent }\end{array}$ & $\begin{array}{l}\text { RNA- } \\
\text { cyclooctyne }\end{array}$ & $\begin{array}{l}\text { Product } \\
\text { (s) }\end{array}$ & $\begin{array}{l}\text { MALDI-TOF MS } \\
\text { calculated, found }\end{array}$ \\
\hline $\mathbf{2 4}$ & $50 \%$ aq. EtOH & $\mathbf{8}$ & $\mathbf{3 3 a}$ & 1595,1596 \\
& & $\mathbf{9}$ & $\mathbf{3 4 a}$ & 3374,3379 \\
& & $\mathbf{7}$ & $\mathbf{3 8}$ & 6607,6611 \\
& & $\mathbf{1 0}$ & $\mathbf{3 9}$ & 2234,2238 \\
$\mathbf{2 5}$ & $50 \%$ aq. EtOH & $\mathbf{8}$ & $\mathbf{4 0}$ & 1958,1960 \\
& & $\mathbf{9}$ & $\mathbf{3 3 b}$ & 1613,1614 \\
$\mathbf{2 6}$ & $50 \%$ aq. EtOH & $\mathbf{8}$ & $\mathbf{3 4 b}$ & 3392,3393 \\
& & $\mathbf{9}$ & $\mathbf{3 3 c}$ & 1645,1647 \\
$\mathbf{2 7}$ & $50 \%$ aq. EtOH & $\mathbf{9}$ & $\mathbf{3 4 c}$ & 3424,3428 \\
$\mathbf{2 8}$ & DMF-EtOH $7: 3$ & $\mathbf{8}$ & $\mathbf{3 3 d}$ & 3434,3436 \\
$\mathbf{2 9}$ & DMF-EtOH $7: 3$ & $\mathbf{8}$ & $\mathbf{3 3 e}$ & 1688,1721 \\
$\mathbf{3 0}$ & DMF-EtOH $7: 3$ & $\mathbf{8}$ & $\mathbf{3 3 f}$ & 1744,1746 \\
\hline
\end{tabular}

the regioisomeric RNA-isoxazole conjugates $\mathbf{3 8}$ whose structural assignment was supported by MALDI-TOF-MS (Scheme 5, Table 3). To illustrate the potential of the SPNOAC to deliver "native" RNA conjugates, i.e. those bearing a free 2'-hydroxyl group either as an alternate or gapmer, sequences $\mathbf{1 0}$ and $\mathbf{1 1}$ were 


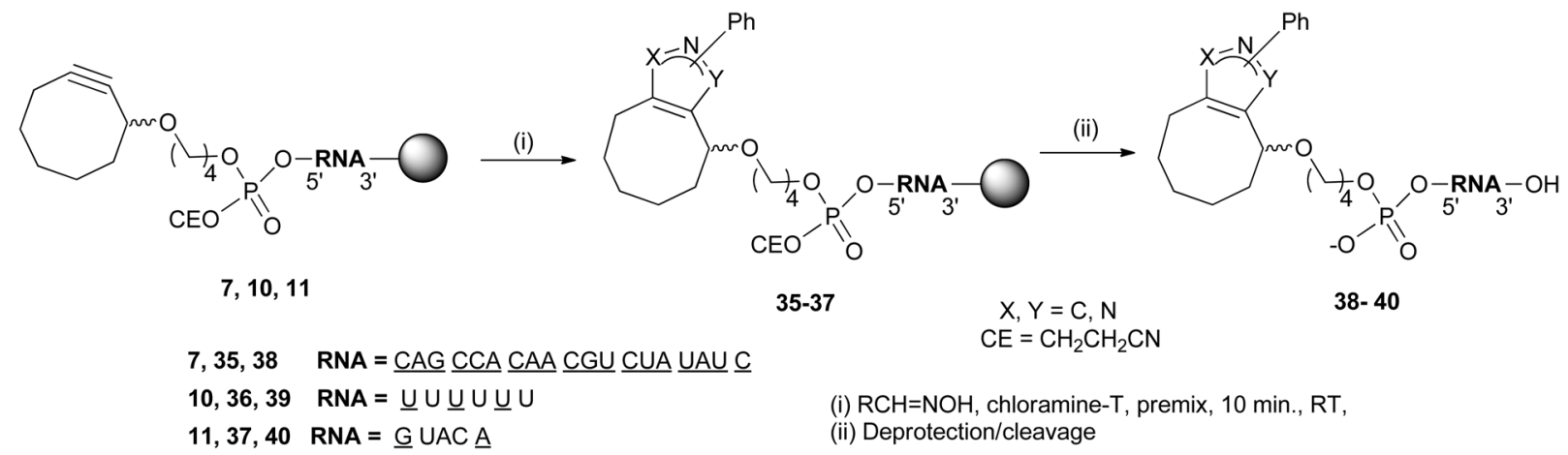

Scheme 5 SPNOAC of RNA-cyclooctynes 7, 10 and $\mathbf{1 1}$ with benzonitrile oxide.

investigated. These sequences have some of the ribose sugars bearing 2'-O-TBDMS protecting groups and others bearing $2^{\prime}$-OMe blocks; thus U6-cyclooctyne 10, has the alternate pattern. The RNA-cyclooctyne 11, with 2'-OMe blocking groups on the ribose units at each terminus and $2^{\prime}-O$-TBDMS protecting groups on the central ribose moieties is defined as a gapmer. Both sequences were tested as substrates in SPNOAC under the standard conditions described above. In each case after $10 \mathrm{~min}$ reaction at room temperature with benzonitrile oxide and following work up, including cleavage from the support, and full (base and sugar) deprotection, HPLC analysis revealed complete conversion to the regioisomeric RNA-isoxazole conjugates 39 and 40 (Scheme 5). MALDI-TOF-MS supported the structural integrity of all new conjugates (Table 3 ).

\section{Conclusions}

We have developed fast, strain promoted cycloaddition as a tool for RNA conjugation on the solid phase exploiting the cycloaddition of a series of RNA-cyclooctynes with both azide (SPAAC) and nitrile oxide dipoles (SPNOAC). The reaction is compatible with $2^{\prime}$-OMe blocking as well as with $2^{\prime}$-O-TBDMS protection on the ribose moieties of the sugar. Nitrile oxides are found to be more reactive dipole partners than azides. The copper free click conjugations proceed in aqueous solvents, in $10 \mathrm{~min}$ at room temperature under atmospheric conditions. The successful ligation to monocyclic alkynes, with reduced steric demands and hydrophobic character relative to diaryl fused analogues, may be of benefit to those applications seeking enhanced aqueous solubility. The SPNOAC reaction, which tolerates dipoles of varying steric bulk and electronic demands, including pyrenyl, coumarinyl and dabcyl provides complementarity to recent reports on copper-promoted and copper free conjugation of, ligase generated, "clickable" RNAs. ${ }^{44,45}$

\section{Experimental section}

\section{General experimental}

Mass analysis was performed on an Applied Biosystem Voyager with 3-hydroxypicolinic acid or 2',4',6'-trihydroxyacetophenone as matrix or recorded by Metabion, Germany. UV analysis was performed on a Jasco V-630BIO spectrophotometer at $25{ }^{\circ} \mathrm{C}$. HPLC was carried out using either using a Gilson instrument equipped with a diode array detector [Nucleosil C18 column $(4.6 \times 250 \mathrm{~mm}, 5 \mu \mathrm{m})$ or Phenomenex C18 column $(4.6 \times$ $250 \mathrm{~mm}, 5 \mu \mathrm{m})]$, or using a Dionex Ultimate 3000 instrument equipped with a Clarity Oligo RP C18 $(4.6 \times 250 \mathrm{~mm}, 5 \mu \mathrm{m})$ column. RNA monomers were purchased from Link Technologies UK. Desalting of oligonucleotide samples was conducted using illustra NAP-10 Sephadex G-25 DNA grade columns purchased from GE Healthcare.

\section{Synthesis of RNA substrates 1-5}

Oligonucleotide syntheses were conducted on an Expedite 8909 DNA/RNA or ABI 394 synthesizer using commercially available 2'-OMe or 2'-O-TBDMS phosphoramidites, and followed standard RNA synthesis protocols.

\section{General procedure for preparation of RNA-cyclooctynes 7-11}

To manually couple the cyclooctyne phosphoramidite $6^{33}$ to the oligonucleotide, $500 \mu \mathrm{L}$ of a $100 \mathrm{mM}$ solution of the phosphoramidite in anhydrous $\mathrm{CH}_{3} \mathrm{CN}$ was added to the CPG-supported oligonucleotide $(1 \mu \mathrm{mol})$ along with $500 \mu \mathrm{L}$ of a $0.3 \mathrm{M}$ solution of 5-benzylmercaptotetrazole in $\mathrm{CH}_{3} \mathrm{CN}$. The mixture was allowed to react for $15 \mathrm{~min}$ at room temperature with mixing between syringes. This procedure was repeated with a second portion of a fresh solution of phosphoramidite and 5-benzylmercaptotetrazole. The $\mathrm{CPG}$ was washed with $\mathrm{CH}_{3} \mathrm{CN}(5 \times$ $2 \mathrm{~mL}$ ), then exposed to oxidizer $(700 \mu \mathrm{L}, 0.1 \mathrm{M}$ iodine solution in THF-pyridine-water; $78: 20: 2$ ). Following washing with $\mathrm{CH}_{3} \mathrm{CN}(2 \times 5 \mathrm{~mL})$ the CPG-support was dried under vacuum using a vacuum concentrator. Cleavage and base deprotection of the cyclooctyne modified 2'-OMe blocked oligonucleotides 7-9, and the alternate or gapmer substrates 10-11, from the support proceeded by the method described below furnishing cyclooctyne-modified RNAs 12-16.

\section{General procedure for oligonucleotide cleavage and deprotection}

For analytical purposes a portion of each oligonucleotide was cleaved from the CPG and protecting groups removed from the base following incubation either in $40 \%(\mathrm{w} / \mathrm{v})$ aqueous $\mathrm{CH}_{3} \mathrm{NH}_{2}$ $(500 \mu \mathrm{L})$ at $65^{\circ} \mathrm{C}$ for $15 \mathrm{~min}$ for substrates 12-16 (method i), or in $28 \%(\mathrm{w} / \mathrm{v})$ aqueous $\mathrm{NH}_{4} \mathrm{OH}(500 \mu \mathrm{L})$ at $25^{\circ} \mathrm{C}$ for $30 \mathrm{~min}$ for 
substrates 33e-f (method ii). The $\mathrm{CH}_{3} \mathrm{NH}_{2} / \mathrm{NH}_{4} \mathrm{OH}$ was evaporated using a concentrator. The $\mathrm{CPG}$ was washed with $\mathrm{H}_{2} \mathrm{O}$ ( $4 \times 200 \mu \mathrm{L}$ aliquots), all solutions and washings were combined to afford an aqueous solution of the oligonucleotide products which were concentrated on a vacuum concentrator prior to HPLC analysis.

\section{Full deprotection of alternate and gapmer oligonucleotides 10-11 and 36-37}

An aqueous sample of the oligonucleotide, cleaved from the solid support and methylamine-deprotected as described above was cooled on ice. The supernatant was decanted and set aside and the support washed with EtOH-MeCN- $\mathrm{H}_{2} \mathrm{O}(1: 1: 3(\mathrm{v} / \mathrm{v} / \mathrm{v})$ $3 \times 150 \mu \mathrm{L})$. The supernatant and washings were combined and evaporated to dryness. Removal of the TBDMS group was effected following treatment with a solution of $N$-methylpyrrolidone-triethylamine-triethylamine tris(hydrofluoride) (6:3:4 $(\mathrm{v} / \mathrm{v} / \mathrm{v}), 250 \mu \mathrm{L})$ at $65{ }^{\circ} \mathrm{C}$ for $1.5 \mathrm{~h}$. The reaction mixture was allowed to cool to room temperature and excess fluoride quenched following addition of isopropyl trimethylsilylether $(500 \mu \mathrm{L})$ with periodic vigorous shaking over a $10 \mathrm{~min}$ period. Diethyl ether $(1 \mathrm{~mL})$ was added and the mixture agitated vigorously. Following centrifugation at $5000 \mathrm{rpm}$, the supernatant was carefully removed and the residual solid pellet re-suspended in triethylammonium acetate buffer $(\mathrm{pH} 7)(1 \mathrm{~mL})$ before analysis by RP-HPLC.

\section{General methods for HPLC analysis}

Cyclooctyne-modified oligonucleotides and click conjugation products were analyzed by reverse-phase HPLC under either conditions A (for products 12-16, 33a-d, 34a-d), conditions B (for products 33e-f, 38-40), or conditions $C$ (for products $\mathbf{2 3 a}-\mathbf{e}$ ).

Conditions A: $200 \mu \mathrm{L}$ injection loop. Buffer A: 0.1 M TEAAc (aq), pH 6.5; Buffer B: 0.1 M TEAAc, pH 6.5, 65\% (v/v) MeCN (aq). Gradient: 0-3 min, 5\% B; 3-23 min, $5 \rightarrow 95 \%$

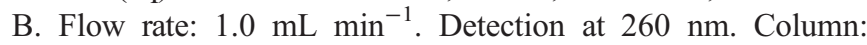
Phenomenex C18 column $(4.6 \times 250 \mathrm{~mm}, 5 \mu \mathrm{m})$.

Conditions B: $20 \mu \mathrm{L}$ injection loop. Buffer A: 0.1 M TEAAc, $\mathrm{pH} 6.5,5 \%(\mathrm{v} / \mathrm{v}) \mathrm{MeCN}(\mathrm{aq})$; Buffer B: $0.1 \mathrm{M}$ TEAAc, $\mathrm{pH}$ 6.5, $65 \%$ (v/v) MeCN (aq). Gradient; 0-5 min, 5\% B; 5-20 min, 5

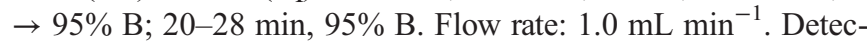
tion at $260 \mathrm{~nm}$. Column: Phenomenex Clarity Oligo C18 column, $5 \mu \mathrm{m}$.

Conditions C: $200 \mu \mathrm{L}$ injection loop. Buffer A: 0.1 M TEAAc (aq), pH 7.6; Buffer B: 0.1 M TEAAc, pH 7.6, 65\% (v/v) MeCN (aq). Gradient: 0-4.3 min, 5\% B; 4.3-16.6 min,

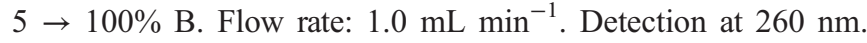
Column: Phenomenex C18 column $(4.6 \times 250 \mathrm{~mm}, 5 \mu \mathrm{m})$

\section{Procedures for click conjugation by SPAAC on the solid phase}

Preparation of conjugates 23a-c. To solid-supported CPG-RNA-cyclooctyne $7(0.12 \mu \mathrm{mol})$ in an Eppendorf tube was added a solution of the azide $(10 \mu \mathrm{L}$ of a $240 \mathrm{mM}$ stock solution in DMSO, $2.4 \mu \mathrm{mol}, 20$ equivalents) and the volume was adjusted to $20 \mu \mathrm{L}$ with DMSO and water according to the solubility of the azide (Table 1). The mixture was agitated at room temperature. After completion of the conjugation reaction (Table 1), the $\mathrm{CPG}$ was washed firstly with $\mathrm{CH}_{3} \mathrm{CN}$ $(5 \times 300 \mu \mathrm{L})$ and then $\mathrm{H}_{2} \mathrm{O}(1 \times 300 \mu \mathrm{L})$. In the case of the biotin cycloadduct 23c, DMSO was used instead of $\mathrm{CH}_{3} \mathrm{CN}$ during the work-up. Cleavage from the solid support, deprotection (method i) and HPLC analysis (conditions C) were followed by the procedures described above to give $23 \mathbf{a}-\mathbf{c}$.

Preparation of cholesterol conjugate, 23d. To solid supported CPG-RNA-cyclooctyne $7(0.12 \mu \mathrm{mol})$ in an Eppendorf tube was added a solution of the cholesteryl azide $20(20 \mu \mathrm{L}$ of a $240 \mathrm{mM}$ stock solution in DCM, $2.4 \mu \mathrm{mol}, 20$ equivalents) and the resulting mixture was agitated at room temperature for $20 \mathrm{~h}$. After completion of the conjugation reaction, the $\mathrm{CPG}$ was washed with DCM $(5 \times 300 \mu \mathrm{L}), \mathrm{CH}_{3} \mathrm{CN}(1 \times 300 \mu \mathrm{L})$ and $\mathrm{H}_{2} \mathrm{O}$ $(1 \times 300 \mu \mathrm{L})$. Cleavage from the support, deprotection (method i) and HPLC analysis (conditions C) were followed by the procedures described above to give $\mathbf{2 3 d}$.

Preparation of fluorescein conjugate, 23e in solution phase. Following deprotection and cleavage from the solid support (method i), a solution of RNA-cyclooctyne $12(125 \mu \mathrm{L}, 200 \mu \mathrm{M}$, $0.025 \mu \mathrm{mol})$ was evaporated to dryness. To this was added a solution of the fluorescein azide $21(9.0 \mu \mathrm{L}$ of a $112 \mathrm{mM}$ stock solution in DMF, $1.0 \mu \mathrm{mol}, 40$ equivalents) and $\mathrm{H}_{2} \mathrm{O}(0.5 \mu \mathrm{L})$. The resulting solution was agitated for $24 \mathrm{~h}$ at room temperature. $\mathrm{H}_{2} \mathrm{O}(200 \mu \mathrm{L})$ was added and this solution was washed with EtOAc $(10 \times 300 \mu \mathrm{L})$ to remove the excess azide. Any remaining EtOAc was removed under vacuum and the resulting aqueous solution was analysed and purified by reversed-phase HPLC (conditions C) to furnish $\mathbf{2 3 e}$.

\section{Procedures for click conjugation by SPNOAC on the solid phase}

To a suspension of solid supported oligonucleotide-cyclooctynes 7-11 $(0.2 \mu \mathrm{mol})$ in an Eppendorf tube in $100 \mu \mathrm{L}$ of the appropriate solvent (Table 2) was added $10 \mu \mathrm{L}$ of a premixed solution of the oxime $(3.3 \mu \mathrm{mol})$ and chloramine-T monohydrate $(3.3 \mu \mathrm{mol})$ in the stated solvent (Table 2$)$. The combined mixture was agitated at room temperature for $10 \mathrm{~min}$. Following settling the supernatant liquid was removed by syringe and the $\mathrm{CPG}$

Table 4 Washing solvents selected for work-up of isoxazole conjugates

\begin{tabular}{ll}
\hline Product(s) & Washing solvents \\
\hline 33a, 34a & $\mathrm{CH}_{3} \mathrm{CN}(5 \times 300 \mu \mathrm{L}), \mathrm{CH}_{3} \mathrm{OH}(3 \times 200 \mu \mathrm{L}) \mathrm{H}_{2} \mathrm{O}$ \\
38, 39, 40 & $(4 \times 300 \mu \mathrm{L})$. \\
33b, 34b & $\mathrm{CH}_{3} \mathrm{CN}(5 \times 300 \mu \mathrm{L}), \mathrm{CH}_{3} \mathrm{OH}(3 \times 200 \mu \mathrm{L}) \mathrm{H}_{2} \mathrm{O}$ \\
& $(4 \times 300 \mu \mathrm{L})$. \\
33c, 34c & $\mathrm{CH}_{3} \mathrm{CN}(5 \times 300 \mu \mathrm{L}), \mathrm{CH}_{3} \mathrm{OH}(3 \times 200 \mu \mathrm{L}) \mathrm{H}_{2} \mathrm{O}$ \\
& $(4 \times 300 \mu \mathrm{L})$. \\
34d & $\mathrm{CH}_{3} \mathrm{CN}(5 \times 300 \mu \mathrm{L}), \mathrm{CH}_{3} \mathrm{OH}(3 \times 200 \mu \mathrm{L}) \mathrm{H}_{2} \mathrm{O}$ \\
& $(4 \times 300 \mu \mathrm{L})$. \\
33d & $\mathrm{DMF}(5 \times 300 \mu \mathrm{L}), \mathrm{CH}_{3} \mathrm{OH}(3 \times 200 \mu \mathrm{L}) \mathrm{H}_{2} \mathrm{O}$ \\
& $(4 \times 300 \mu \mathrm{L})$. \\
33e & $\mathrm{DMF}(5 \times 300 \mu \mathrm{L}), \mathrm{CH}_{3} \mathrm{OH}(3 \times 200 \mu \mathrm{L}) \mathrm{H}_{2} \mathrm{O}$ \\
33f & $(4 \times 300 \mu \mathrm{L})$. \\
& $\mathrm{DMF}(5 \times 300 \mu \mathrm{L}), \mathrm{CH}_{3} \mathrm{OH}(3 \times 200 \mu \mathrm{L}) \mathrm{H}_{2} \mathrm{O}$ \\
& $(4 \times 300 \mu \mathrm{L})$. \\
\hline
\end{tabular}


washed as outlined in the Table 4 below. Cleavage from the solid support, deprotection (method i) and HPLC analysis (conditions $\mathrm{A}$ and $\mathrm{B}$ ) were followed by the procedures described above.

\section{Acknowledgements}

Financial support from the Science Foundation of Ireland (Programme code 05/PICA/B838) is gratefully acknowledged. $\mathrm{CF}$ is grateful to the Irish Research Council Science and Engineering for receipt of an Embark Postgraduate Research Scholarship (Programme code RS/2007/48). The authors are grateful to Dr Glenn Burley (Department of Pure and Applied Chemistry, 295 Cathedral Street, University of Strathclyde Glasgow, G1 1XL, UK) for assistance with HPLC analysis.

\section{Notes and references}

1 Y. Singh, P. Murat and E. Defrancq, Chem. Soc. Rev., 2010, 39, 2054-2070.

2 R. L. Juliano, X. Ming and O. Nakagawa, Acc. Chem. Res., 2012, DOI: $10.1021 /$ ar2002123.

3 N. M. Bell and J. Micklefield, ChemBioChem, 2009, 10, 2691-2703.

4 M. Endo and H. Sugiyama, ChemBioChem, 2009, 10, 2420-2443.

5 J. Lahann, Click Chemistry for Biotechnology and Material Science, Wiley, Chichester, U.K., 2009.

6 H. C. Kolb, M. G. Finn and K. B. Sharpless, Angew. Chem., Int. Ed, 2001, 40, 2005-2021.

7 J.-F. Lutz, Angew. Chem., Int. Ed., 2007, 46, 1018-1025.

8 J. Gierlich, G. A. Burley, P. M. E. Gramlich, D. M. Hammond and T. Carell, Org. Lett., 2006, 8, 3639-3642.

9 A. H. El-Sagheer and T. Brown, Chem. Soc. Rev., 2010, 39, 1388-1405.

10 R. Kumar, A. El-Sagheer, J. Tumpane, P. Lincoln, L. M. Wilhelmsson and T. Brown, J. Am. Chem. Soc., 2007, 129, 6859-6864.

11 P. M. E. Gramlich, C. T. Wirges, A. Manetto and T. Carell, Angew. Chem., Int. Ed., 2008, 47, 8350-8358.

12 L. M. Gaetke and C. K. Chow, Toxicology, 2003, 189, 147-163.

13 I. Singh, J. S. Vyle and F. Heaney, Chem. Commun., 2009, 45, 3276-3278.

14 I. Singh and F. Heaney, Org. Biomol. Chem., 2010, 8, 451-456.

15 K. Gutsmiedl, C. T. Wirges, V. Ehmke and T. Carell, Org. Lett., 2009, 11, $2405-2408$.

16 K. Gutsmiedl, D. Fazio and T. Carell, Chem.-Eur. J., 2010, 16, 6877-6883.

17 V. Algay, I. Singh and F. Heaney, Org. Biomol. Chem., 2010, 8, 391-397.

18 I. Singh, Z. Zarafshani, J.-F. Lutz and F. Heaney, Macromolecules, 2009, 42, 5411-5413.

19 I. Singh, Z. Zarafshani, F. Heaney and J.-F. Lutz, Polym. Chem., 2011, 2 , $372-375$.
20 D. Graham and A. Enright, Curr. Org. Synth., 2006, 3, 9-17.

21 W. Song, Y. Wang, J. Qu and Q. Lin, J. Am. Chem. Soc., 2008, 130, 9654-9655.

22 J. Schoch, M. Wiessler and A. Jäschke, J. Am. Chem. Soc., 2010, 132, $8846-8847$.

23 N. J. Agard, J. A. Prescher and C. R. Bertozzi, J. Am. Chem. Soc., 2004, 126, 15046-15047.

24 E. M. Sletten and C. R. Bertozzi, Org. Lett., 2008, 10, 3097-3099.

25 A. A. Poloukhtine, N. E. Mbua, M. A. Wolfert, G.-J. Boons and V. V. Popik, J. Am. Chem. Soc., 2009, 131, 15769-15776.

26 J. C. Jewett, E. M. Sletten and C. R. Bertozzi, J. Am. Chem. Soc., 2010, 132, 3688-3690.

27 P. V. Chang, J. A. Prescher, E. M. Sletten, J. M. Baskin, I. A. Miller, N. J. Agard, A. Lo and C. R. Bertozzi, Proc. Natl. Acad. Sci. U. S. A., 2010, 107, 1821-1826.

28 M. E. Martin, S. G. Parameswarappa, M. S. O’Dorisio, F. C. Pigge and M. K. Schultz, Bioorg. Med. Chem. Lett., 2010, 20, 4805-4807.

29 E. Lallana, R. Riguera and E. Fernandez-Megia, Angew. Chem., Int. Ed., 2011, 50, 8794-8804.

30 L. A. Canalle, S. S. van Berkel, L. T. de Haan and J. C. M. van Hest, Adv. Funct. Mater., 2009, 19, 3464-3470.

31 A. Kuzmin, A. Poloukhtine, M. A. Wolfert and V. V. Popik, Bioconjugate Chem., 2010, 21, 2076-2085.

32 I. Singh, C. Freeman and F. Heaney, Eur. J. Org. Chem., 2011, 2011, 6739-6746.

33 I. Singh and F. Heaney, Chem. Commun., 2011, 47, 2706-2708.

34 P. v. Delft, N. J. Meeuwenoord, S. Hoogendoorn, J. Dinkelaar, H. S. Overkleeft, G. A. v. d. Marel and D. V. Filippov, Org. Lett., 2010, 12, 5486-5489.

35 K. N. Jayaprakash, C. G. Peng, D. Butler, J. P. Varghese, M. A. Maier, K. G. Rajeev and M. Manoharan, Org. Lett., 2010, 12, 5410-5413.

36 M. Shelbourne, X. Chen, T. Brown and A. H. El-Sagheer, Chem. Commun., 2011, 47, 6257-6259.

37 M. F. Debets, S. S. van Berkel, J. Dommerholt, A. J. Dirks, F. P. J. T. Rutjes and F. L. van Delft, Acc. Chem. Res., 2011, 44, $805-815$.

38 F. Shi, J. P. Waldo, Y. Chen and R. C. Larock, Org. Lett., 2008, 10, 2409-2412.

39 T. Yamada, C. G. Peng, S. Matsuda, H. Addepalli, K. N. Jayaprakash, M. R. Alam, K. Mills, M. A. Maier, K. Charisse, M. Sekine, M. Manoharan and K. G. Rajeev, J. Org. Chem., 2011, 76, 1198-1211.

40 M. F. Debets, C. W. J. van der Doelen, F. P. J. T. Rutjes and F. L. van Delft, ChemBioChem, 2010, 11, 1168-1184.

41 V. Bouvet, M. Wuest and F. Wuest, Org. Biomol. Chem., 2011, 9, 7393-7399.

42 F. B. Mallory and C. W. Mallory, J. Am. Chem. Soc., 1985, 107, 4816-4819.

43 H. E. Master, S. I. Khan and K. A. Poojari, Bioorg. Med. Chem., 2005, 13, 4891-4899.

44 E. Paredes and S. R. Das, ChemBioChem, 2011, 12, 125-131.

45 M.-L. Winz, A. Samanta, D. Benzinger and A. Jäschke, Nucleic Acids Res., 2012, 40, e78. 